\title{
Inhibition of Erythrocyte Cell Membrane Scrambling by ASP3026
}

\author{
Abdulla Al Mamun Bhuyan ${ }^{\mathrm{a}}$ Rosi Bissinger ${ }^{\mathrm{a}}$ Hang Cao ${ }^{\mathrm{a}}$ Florian Lang ${ }^{\mathrm{b}, \mathrm{c}}$ \\ aDepartment of Internal Medicine III, Eberhard-Karls-University of Tuebingen, ${ }^{b}$ Department of Molecular \\ Medicine II, Medical Faculty, Heinrich Heine University, Duesseldorf, 'Department of Physiology I, \\ Eberhard-Karls-University of Tuebingen, Germany
}

\section{Key Words}

Phosphatidylserine $\bullet$ Eryptosis $•$ Energy depletion $•$ Oxidative stress $\bullet$ Ionomycin $•$ Calcium

\begin{abstract}
Background/Aims: The anaplastic lymphoma kinase (ALK) inhibitor ASP3026 is in clinical development for the treatment of ALK expressing non-small cell lung carcinoma (NSCLC). ASP3026 is in part effective by inducing apoptosis of tumor cells. Erythrocytes lack mitochondria and nuclei, key organelles in the execution of apoptosis, but are nevertheless able to enter suicidal death or eryptosis, which is characterized by cell membrane scrambling with phosphatidylserine translocation to the cell surface and by cell shrinkage. Eryptosis is triggered by cell stress, such as energy depletion, hyperosmotic shock, oxidative stress and excessive increase of cytosolic $\mathrm{Ca}^{2+}$ activity $\left(\left[\mathrm{Ca}^{2+}\right]_{i}\right)$. The present study explored, whether ASP3026 impacts on eryptosis. Methods: Human erythrocytes have been exposed to energy depletion (glucose withdrawal for 48 hours), oxidative stress (addition of $0.3 \mathrm{mM}$ tert-butylhydroperoxide $[\mathrm{tBOOH}]$ for $50 \mathrm{~min}$ ) or $\mathrm{Ca}^{2+}$ loading with $\mathrm{Ca}^{2+}$ ionophore ionomycin ( $1 \mu \mathrm{M}$ for $60 \mathrm{~min}$ ) in absence and presence of ASP3026 (1-4 $\mathrm{\mu g} / \mathrm{ml})$. Flow cytometry was employed to quantify phosphatidylserine exposure at the cell surface from annexin-V-binding, and cell volume from forward scatter. Results: Treatment with ASP3026 alone did not significantly modify annexinV-binding or forward scatter. Energy depletion, oxidative stress and ionomycin, all markedly and significantly increased the percentage of annexin-V-binding erythrocytes, and decreased the forward scatter. ASP3026 significantly blunted the effect of energy depletion and oxidative stress, but not of ionomycin on annexin-V-binding. ASP3026 did not significantly influence the effect of any maneuver on forward scatter. Conclusions: ASP3026 is a novel inhibitor of erythrocyte cell membrane scrambling following energy depletion and oxidative stress.
\end{abstract}

\section{Introduction}

(C) 2017 The Author(s)

Published by S. Karger AG, Basel

The anaplastic lymphoma kinase (ALK) originally detected in anaplastic large cell lymphomas (ALCL) [1] plays a decisive pathophysiological role in several solid tumors [1],

Florian Lang

KARGER
Department of Physiology I, University of Tuebingen, Gmelinstr. 5,

72076 Tuebingen (Germany)

Tel. +49 7071 29-72194, Fax +49 7071 29-5618, E-Mail florian.lang@uni-tuebingen.de 
including ALK expressing non-small cell lung carcinoma (NSCLC). Inhibitors of ALK include ASP3026 [2, 3], which is in clinical development for the treatment of ALK expressing NSCLC [2-5]. ASP3026 is in part effective by inducing apoptotic tumor cell death [6].

ALK expressing cells include eythrocytes [7], which may enter eryptosis, an apoptosislike suicidal erythrocyte death [8]. Eryptosis is characterized by cell membrane scrambling with phosphatidylserine translocation to the cell surface [8]. Another hallmark of eryptosis is cell shrinkage [9]. Cellular mechanisms orchestrating the triggering of eryptosis include increase of cytosolic $\mathrm{Ca}^{2+}$ activity $\left(\left[\mathrm{Ca}^{2+}\right]_{\mathrm{i}}\right)[8]$, ceramide [10], caspases $[8,11,12]$, G-protein $\mathrm{G \alpha}_{\mathrm{i} 2}$ [13], casein kinase $1 \alpha$ [8], Janus-activated kinase JAK3 [8], protein kinase C [8], and p38 kinase [8]. Eryptosis is inhibited by several kinases, including AMP activated kinase AMPK [8], cGMP-dependent protein kinase [8], mitogen and stress activated kinase MSK1/2 [14], PAK2 kinase [8] and sorafenib/sunitinib sensitive kinases [8]. Triggers of eryptosis include hyperosmotic shock [8], oxidative stress [8], energy depletion [8], exposure to a plethora of xenobiotics [8, 14-70], and diverse clinical conditions including iron deficiency [8], dehydration [71], hyperphosphatemia [72], vitamin D excess [73], chronic kidney disease (CKD) [74-78], hemolytic-uremic syndrome [79], diabetes [80], hepatic failure [45, 81], malignancy [78, 82], arteritis [83], sepsis [84], sickle-cell disease [8], beta-thalassemia [8], $\mathrm{Hb}-\mathrm{C}$ and G6PD-deficiency [8], lung cancer [85], Wilsons disease [86], as well as advanced age [87]. Eryptosis is further observed following blood storage for transfusion [88]. Eryptosis may be inhibited by several substances [8].

The present study explored, whether ASP3026 influences eryptosis. To this end, human erythrocytes from healthy volunteers were exposed to ASP3026 without or with additional exposure to energy depletion, oxidative stress, and $\mathrm{Ca}^{2+}$ loading with $\mathrm{Ca}^{2+}$ ionophore ionomycin. Phosphatidylserine surface abundance and cell volume were subsequently determined utilizing flow cytometry.

\section{Materials and Methods}

Erythrocytes, solutions and chemicals

Fresh Li-Heparin-anticoagulated blood samples were kindly provided by the blood bank of the University of Tübingen. The study is approved by the ethics committee of the University of Tübingen (184/2003 V). The blood was centrifuged at $120 \mathrm{~g}$ for $20 \mathrm{~min}$ at $21^{\circ} \mathrm{C}$ and the platelets and leukocytes-containing supernatant was disposed. Erythrocytes were incubated in vitro at a hematocrit of $0.4 \%$ in Ringer solution containing (in $\mathrm{mM}$ ) $125 \mathrm{NaCl}, 5 \mathrm{KCl}, 1 \mathrm{MgSO}_{4}$, $32 \mathrm{~N}$-2-hydroxyethylpiperazine-N-2-ethanesulfonic acid (HEPES; pH 7.4), 5 glucose, 1 $\mathrm{CaCl}_{2}$, at $37^{\circ} \mathrm{C}$ for 48 hours. Where indicated, erythrocytes were exposed for 48 hours to glucose depleted Ringer solution, for 50 minutes to the oxidant tert-butyl-hydroperoxide ( $0.3 \mathrm{mM}$, Sigma Aldrich, Hamburg, Germany), or for 60 minutes to $\mathrm{Ca}^{2+}$ ionophore ionomycin (1 $\mu \mathrm{M}$, Merck Millipore, Darmstadt, Germany), each in the absence and presence of ASP3026 (MedChem Express, Princeton, USA) or, as control, the solvent DMSO alone. As ASP3026 plasma concentrations higher than $1 \mu \mathrm{g} / \mathrm{ml}$ ASP3026 have been observed in humans, ASP3026 concentrations of $1-4 \mu \mathrm{g} / \mathrm{ml}$ have been tested.

Annexin-V-binding and forward scatter

After incubation under the respective experimental condition, a $150 \mu \mathrm{l}$ cell suspension was washed in Ringer solution containing $5 \mathrm{mM} \mathrm{CaCl}_{2}$ and then stained with Annexin-V-FITC (1:200 dilution; ImmunoTools, Friesoythe, Germany) in this solution at $37^{\circ} \mathrm{C}$ for $15 \mathrm{~min}$ under protection from light. The annexin-Vabundance at the erythrocyte surface was subsequently determined on a FACS Calibur (BD, Heidelberg, Germany). Annexin-V-binding was measured with an excitation wavelength of $488 \mathrm{~nm}$ and an emission wavelength of $530 \mathrm{~nm}$. A marker (M1) was placed to set an arbitrary threshold between annexin-V-binding cells and control cells. The same threshold was used for untreated and ASP3026 treated erythrocytes. A dot plot of forward scatter (FSC) vs. side scatter (SSC) was set to linear scale for both parameters.

Statistics

Data are expressed as arithmetic means \pm SEM. As indicated in the figure legends, statistical analysis was made using ANOVA with Tukey's test as post-test; $n$ denotes the number of different erythrocyte specimens 


\section{Cellular Physiology Cell Physiol Biochem 2017;43:507-517 \begin{tabular}{l|l} 
and Biochemistry Published online: September 20, 2017 & $\begin{array}{l}\text { (C) } 2017 \text { The Author(s). Published by S. Karger AG, Basel } \\
\text { www.karger.com/cpb }\end{array}$
\end{tabular} \\ Al Mamun Bhuyan et al.: ASP3026-Induced Eryptosis}

studied. Since different erythrocyte specimens used in distinct experiments are differently susceptible to triggers of eryptosis, the same erythrocyte specimens have been used for control and experimental conditions.

\section{Results}

In order to test, whether ASP3026 influences eryptosis, eryptotic erythrocytes were identified from the two hallmarks of eryptosis, i.e. phospholipid scrambling of the cell membrane and decrease of cell volume. Cell membrane scrambling was evidenced by annexin-V-binding to phosphatidylserine at the erythrocyte surface, and cell shrinkage was quantified utilizing forward scatter in flow cytometry.

The percentage of human erythrocytes binding annexin-V after 48 hours incubation in standard, glucose containing, Ringer solution was low $(1.86 \pm 0.17 \%, \mathrm{n}=14)$ and not significantly modified by the presence of $4 \mu \mathrm{g} / \mathrm{ml}$ ASP3026 $(2.92 \pm 0.53 \%, \mathrm{n}=14)$. Thus, in standard glucose containing Ringer solution, ASP3026 did not appreciably modify erythrocyte cell membrane scrambling. As illustrated in Fig. 1, glucose removal was followed by a marked increase of the percentage of annexin-V-binding erythrocytes. The addition of ASP3026 (1-4

Fig. 1. ASP3026 sensitivity of phosphatidylserine exposure following energy depletion. A. Original histograms of annexin-V-binding of erythrocytes following exposure for 48 hours to glucose containing Ringer solution (grey area), Ringer solution without glucose (black solid line) and Ringer solution without glucose and presence of

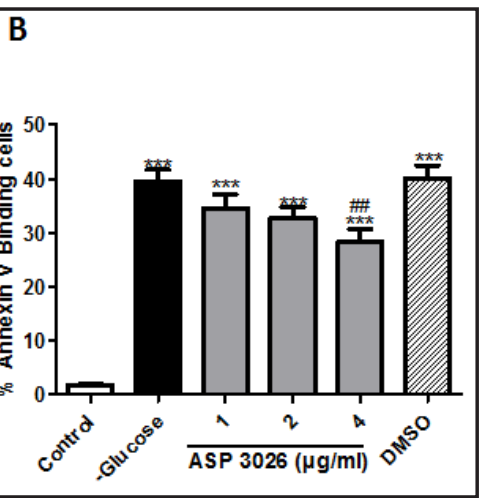

ASP3026 (4 $\mu \mathrm{g} / \mathrm{ml})$ (black dashed line). B. Arithmetic means \pm SEM $(\mathrm{n}=15)$ of the percentage of annexinV-binding erythrocytes after a 48 hours treatment with Ringer solution with glucose (white bar) or without glucose in the absence (black bar) and presence (grey bars) of ASP3026 (1-4 $\mu \mathrm{g} / \mathrm{ml}$ ). For comparison, the value in absence of glucose and presence of the solvent DMSO is shown (striped bar). ${ }^{* * *}(\mathrm{p}<0.001)$ indicates significant difference from the presence of glucose, $\# \#(\mathrm{p}<0.01)$ indicates significant difference from the absence of ASP3026 (ANOVA).

Fig. 2. ASP3026 sensitivity of erythrocyte shrinkage following energy depletion. A. Original histograms of forward scatter of erythrocytes following exposure for 48 hours to glucose containing Ringer solution (grey area), Ringer solution without glucose (black solid line) and Ringer solution without glucose and presence of ASP3026 (4 $\mu \mathrm{g} / \mathrm{ml})$ (black

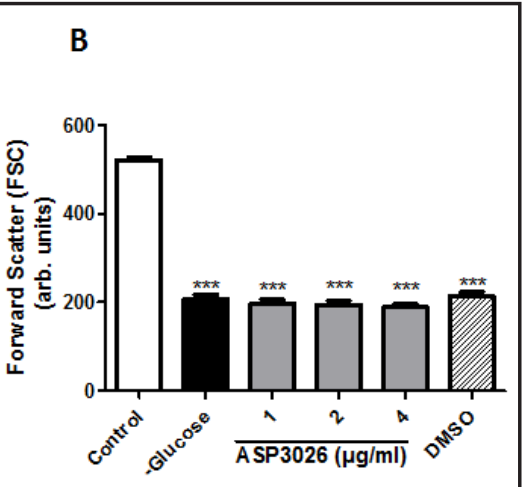

dashed line). B. Arithmetic means \pm SEM $(n=15)$ of the erythrocyte forward scatter after a 48 hours treatment with Ringer solution with glucose (white bar) or without glucose in the absence (black bar) and presence (grey bars) of ASP3026 (1-4 $\mathrm{g} / \mathrm{ml})$. For comparison, the value in absence of glucose and presence of the solvent DMSO is shown (striped bar). ${ }^{* * *}(\mathrm{p}<0.001)$ indicates significant difference from the presence of glucose (ANOVA). 
Fig. 3. ASP3026 sensitivity of phosphatidylserine exposure following oxidative stress. A. Original histograms of annexin-V-binding of erythrocytes following exposure for 50 min to Ringer solution without tert-butylhydroperoxide (grey area), or Ringer solution with tert-butylhydroperoxide $(0.3 \mathrm{mM})$ and absence (solid black line) or

A

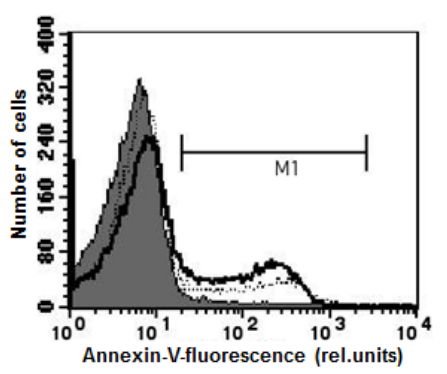

B

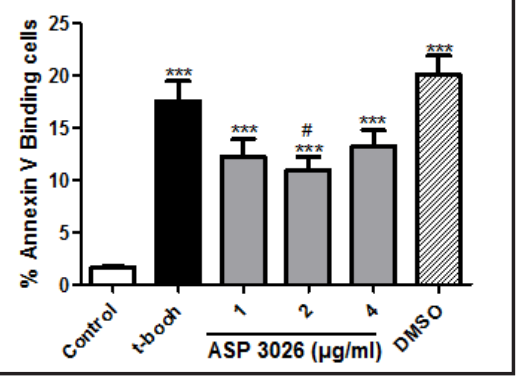

presence (black dashed line) of ASP3026 $(4 \mu \mathrm{g} / \mathrm{ml})$. B. Arithmetic means \pm SEM $(\mathrm{n}=15)$ of the percentage of annexin-V-binding erythrocytes after a 50 min treatment with Ringer solution without tert-butylhydroperoxide (white bar) or with tert-butylhydroperoxide $(0.3 \mathrm{mM})$ in the absence (black bar) and presence (grey bars) of ASP3026 (1-4 $\mu \mathrm{g} / \mathrm{ml})$. For comparison, the value in presence of tert-butylhydroperoxide and DMSO is shown. ${ }^{* * *}(\mathrm{p}<0.001)$ indicates significant difference from the absence of tert-butylhydroperoxide, $\#(\mathrm{p}<0.05)$ indicates significant difference from the absence of ASP3026 (ANOVA).

Fig. 4. ASP3026 sensitivity of erythrocyte shrinkage following oxidative stress. A. Original histograms of erythrocyte forward scatter following exposure for 50 min to Ringer solution without tert-butylhydroperoxide (grey area), or Ringer solution with tert-butylhydroperoxide $(0.3 \mathrm{mM})$ and absence (solid black line) or

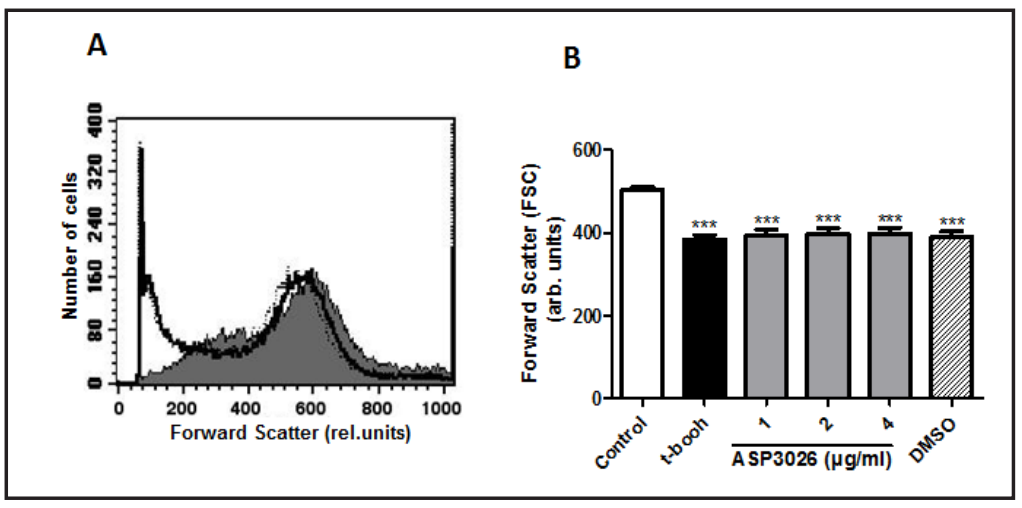
presence (black dashed line) of ASP3026 (4 $\mu \mathrm{g} / \mathrm{ml})$. B. Arithmetic means \pm SEM $(\mathrm{n}=15)$ of erythrocyte forward scatter after a 50 min treatment with Ringer solution without tert-butylhydroperoxide (white bar) or with tert-butylhydroperoxide $(0.3 \mathrm{mM})$ in the absence (black bar) and presence (grey bars) of ASP3026 (1-4 $\mu \mathrm{g} / \mathrm{ml})$. For comparison, the value in presence of tert-butylhydroperoxide and DMSO is shown. ${ }^{* * *}(\mathrm{p}<0.001)$ indicates significant difference from the absence of tert-butylhydroperoxide (ANOVA).

$\mu \mathrm{g} / \mathrm{ml}$ ) blunted the increase of the percentage of annexin-V-binding erythrocytes following glucose deprivation, an effect reaching statistical significance at $4 \mu \mathrm{g} / \mathrm{ml}$ ASP3026 (Fig. 1). Nevertheless, even in the presence of ASP3026, energy depletion significantly increased the percentage of phosphatidylserine exposing erythrocytes (Fig. 1). ASP3026 thus partially prevented cell membrane scrambling following energy depletion,

Erythrocyte forward scatter was, following a 48 hours exposure to Ringer solution in the presence of glucose, again similar in the absence $(508.40 \pm 6.40, \mathrm{n}=14)$ and presence $(503.40 \pm 5.12, \mathrm{n}=14)$ of ASP3026 $(4 \mu \mathrm{g} / \mathrm{ml})$. Accordingly, in standard glucose containing Ringer solution, ASP3026 did not appreciably modify erythrocyte volume. As illustrated in Fig, 2, a 48 hours exposure to glucose-depleted Ringer solution was followed by a marked decrease of forward scatter, reflecting erythrocyte shrinkage. The decline of erythrocyte forward scatter was, following a 48 hours exposure to Ringer solution in the absence of glucose, virtually identical in the absence and presence of ASP3026 (1-4 $\mu \mathrm{g} / \mathrm{ml}$ ) (Fig. 2). Accordingly, neither in energy repleted nor in energy depleted erythrocytes, ASP3026 did significantly modify erythrocyte volume. 
Fig. 5. ASP3026 sensitivity of phosphatidylserine exposure following $\mathrm{Ca}^{2+}$ loading. A. Original histograms of annexin-V-binding of erythrocytes following exposure for 60 min to Ringer solution without $\mathrm{Ca}^{2+}$ ionophore ionomycin (grey area), or Ringer solution with ionomycin $(1 \mu \mathrm{M})$ and absence (solid black line) or presence (black dashed line) of ASP3026 (4 $\mu \mathrm{g} / \mathrm{ml})$. B. Arithmetic means \pm SEM $(\mathrm{n}=10)$ of the percentage of annexin-V-binding erythrocytes after a 60 min treatment with Ringer solution without ionomycin (white bar) or with ionomycin $(1 \mu \mathrm{M})$ in the absence (black bar) and presence (grey bars) of ASP3026 (1-4 $\mu \mathrm{g} / \mathrm{ml})$. For comparison, the value in presence of ionomycin and DMSO is shown. ${ }^{* * *}(\mathrm{p}<0.001)$ indicates significant difference from the absence of ionomycin (ANOVA).

Fig. 6. ASP3026 sensitivity of erythrocyte shrinkage following $\mathrm{Ca}^{2+}$ loading. A. Original histograms of erythrocyte forward scatter following exposure for $60 \mathrm{~min}$ to Ringer solution without ionomycin (grey area), or Ringer solution with ionomycin $(1 \mu \mathrm{M})$ and absence (solid black line) or presence (black dashed line) of ASP3026 ( $4 \mu \mathrm{g} / \mathrm{ml})$. B.

\section{B}

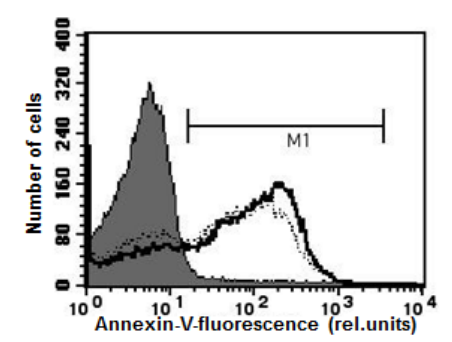

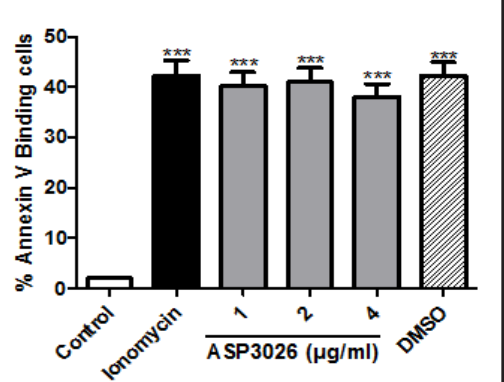

Arithmetic means \pm SEM $(\mathrm{n}=10)$ of erythrocyte forward scatter after a 60 min treatment with Ringer solution without ionomycin (white bar) or with ionomycin $(1 \mu \mathrm{M})$ in the absence (black bar) and presence (grey bars) of ASP3026 (1-4 $\mathrm{\mu g} / \mathrm{ml})$. For comparison, the value in presence of ionomycin and DMSO is shown. $* * *(\mathrm{p}<0.001)$ indicates significant difference from the absence of ionomycin (ANOVA).

A next series of experiments addressed the effect of oxidative stress due to addition of 0.3 $\mathrm{mM}$ tert-butylhydroperoxide ( $\mathrm{tBOOH})$ for 50 minutes. As illustrated in Fig. 3, oxidative stress was followed by a marked increase of the percentage of annexin-V-binding erythrocytes. The addition of ASP3026 (1-4 $\mathrm{gg} / \mathrm{ml})$ blunted the increase of the percentage of annexin-V-binding erythrocytes following oxidative stress, an effect reaching statistical significance at $2 \mu \mathrm{g} /$ ml ASP3026 (Fig. 3). Again, even in the presence of ASP3026, oxidative stress significantly increased the percentage of phosphatidylserine exposing erythrocytes (Fig. 3). ASP3026 thus partially blunted cell membrane scrambling following oxidative stress.

Oxidative stress was further followed by a marked decrease of forward scatter, reflecting erythrocyte shrinkage (Fig. 4). The erythrocyte shrinkage following oxidative stress was virtually identical in the absence and presence of ASP3026 (1-4 $\mu \mathrm{g} / \mathrm{ml}$ ) (Fig. 4). Accordingly, ASP3026 did not significantly interfere with the effect of oxidative stress on erythrocyte volume.

A next series of experiments explored the effect of $\mathrm{Ca}^{2+}$ entry, which was achieved by a 60 min exposure of erythrocytes to $\mathrm{Ca}^{2+}$ ionophore ionomycin $(1 \mu \mathrm{M})$. As illustrated in Fig. 5, exposure of the erythrocytes for 60 minutes to $1 \mu \mathrm{M}$ ionomycin was followed by a sharp increase of the percentage of annexin-V-binding erythrocytes. The effect tended to be 


\section{Cellular Physiology Cell Physiol Biochem 2017;43:507-517

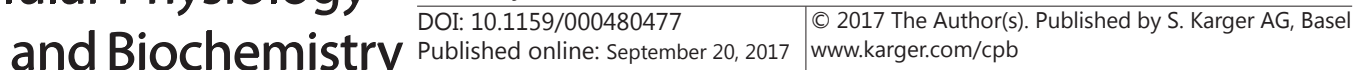

Al Mamun Bhuyan et al.: ASP3026-Induced Eryptosis

slightly blunted by ASP3026, an effect, however, not reaching statistical significance (Fig. 5). Instead, even in the presence of ASP3026, ionomycin significantly increased the percentage of phosphatidylserine exposing erythrocytes (Fig. 5).

Exposure of the erythrocytes for 60 minutes to $1 \mu \mathrm{M}$ ionomycin was followed by a sharp decrease of forward scatter (Fig. 6). The cell shrinkage was not significantly modified by ASP3026 (Fig. 6).

\section{Discussion}

The present observations uncover a novel inhibitor of eryptosis, i.e. the anaplastic lymphoma kinase (ALK) inhibitor [2, 3] ASP3026. In the absence of eryptosis stimulating challenges, ASP3026 did not appreciably influence cell membrane scrambling or cell shrinkage, the two hallmarks of eryptosis [8]. However, the substance significantly blunted the stimulating effect of energy depletion and oxidative stress on cell membrane scrambling. The ASP3026 concentrations required for this effect were well in the range of concentrations encountered in the plasma of patients [89]. The effect of ASP3026 on oxidative stress induced cell membrane scrambling reached statistical significance at 2 but not at 1 and $4 \mu \mathrm{g} / \mathrm{ml}$ ASP3026. The data do, however, not allow the conclusion that ASP3026 was more effective at 2 than at 1 or $4 \mu \mathrm{g} / \mathrm{ml}$. ASP3026 did not appreciably influence the cell membrane scrambling following $\mathrm{Ca}^{2+}$ loading with the $\mathrm{Ca}^{2+}$ ionophore ionomycin. Moreover, ASP3026 did not interfere appreciably with the erythrocyte shrinkage following treatment with energy depletion, oxidative stress, or ionomycin.

The present observations were compatible with the assumption that stimulation of cell membrane scrambling requires ALK activity. However, the effects of ASP3026 are not necessarily due to ALK inhibition but may result from unspecific side effects of the drug. Future experimental effort is required to disclose the cellular mechanisms linking ASP3026 to cell membrane scrambling during energy depletion and oxidative stress, but not following flooding the cells with $\mathrm{Ca}^{2+}$.

Irrespective of the underlying mechanisms, the inhibition of erythrocyte cell membrane scrambling by ASP3026 may counteract anemia in malignancy, a major clinical problem [90-98]. Following triggering of cell membrane scrambling, phosphatidylserine exposing erythrocytes are rapidly cleared from circulating blood and eryptosis leads to anemia as soon as the loss of eryptotic erythrocytes outcasts the formation of new erythrocytes by erythropoiesis [8]. The anemia of malignancy is at least in part due to stimulation of eryptosis [78, 82], and would thus be amenable to inhibitors of cell membrane scrambling.

As ASP3026 did not interfere with cell shrinkage, it does not disrupt the attempt of dying erythrocytes to avoid cell swelling with subsequent hemolysis. Hemoglobin released following hemolysis may otherwise pass the renal glomerular filter, precipitate in the acidic lumen of renal tubules, occlude nephrons and may thus lead to renal failure [99].

Besides the impact of eryptosis on anemia, phosphatidylserine exposing erythrocytes may adhere to the vascular wall [100], stimulate blood clotting/thrombosis [101-103], and interfere with microcirculation [10, 101, 104-107]. Those negative effects of eryptosis are presumably counteracted by inhibitors of cell membrane scrambling, such as ASP3026.

In conclusion, ASP3026 inhibits erythrocyte cell membrane scrambling following energy depletion and oxidative stress thus counteracting suicidal erythrocyte death and subsequent development of anemia.

\section{Acknowledgements}

The authors acknowledge the meticulous preparation of the manuscript by Lejla Subasic. The study was supported by the Deutsche Forschungsgemeinschaft and Open Access Publishing Fund of Tuebingen University. Work of R.B. is supported by the Institutional Strategy of the University of Tübingen (Deutsche Forschungsgemeinschaft, ZUK 63). 


\section{Cellular Physiology Cell Physiol Biochem 2017;43:507-517 \begin{tabular}{ll|l} 
DOI: 10.1159/000480477 & $\begin{array}{l}\text { O } 2017 \text { The Author(s). Published by S. Karger AG, Basel } \\
\text { www.karger.com/cpb }\end{array}$
\end{tabular} \\ Al Mamun Bhuyan et al.: ASP3026-Induced Eryptosis}

\section{Disclosure Statement}

None.

\section{References}

1 Iragavarapu C, Mustafa M, Akinleye A, Furqan M, Mittal V, Cang S, Liu D: Novel ALK inhibitors in clinical use and development. J Hematol Oncol 2015;8:17.

-2 Sullivan I, Planchard D: ALK inhibitors in non-small cell lung cancer: the latest evidence and developments. Ther Adv Med Oncol 2016;8:32-47.

-3 Simionato F, Frizziero M, Carbone C, Tortora G, Melisi D: Current Strategies to Overcome Resistance to ALKInhibitor Agents. Curr Drug Metab 2015;16:585-596.

4 Pall G: The next-generation ALK inhibitors. Curr Opin Oncol 2015;27:118-124.

5 Awad MM, Shaw AT: ALK inhibitors in non-small cell lung cancer: crizotinib and beyond. Clin Adv Hematol Oncol 2014;12:429-439.

6 George SK, Vishwamitra D, Manshouri R, Shi P, Amin HM: The ALK inhibitor ASP3026 eradicates NPMALK(+) T-cell anaplastic large-cell lymphoma in vitro and in a systemic xenograft lymphoma model. Oncotarget 2014;5:5750-5763.

7 Martinez-Pinna R, Burillo E, Madrigal-Matute J, Lopez JA, Camafeita E, Torres-Fonseca MM, Llamas-Granda P, Egido J, Michel JB, Blanco-Colio LM, Martin-Ventura JL: Label-free proteomic analysis of red blood cell membrane fractions from abdominal aortic aneurysm patients. Proteomics Clin Appl 2014;8:626-630.

$>8$ Lang E, Lang F: Mechanisms and pathophysiological significance of eryptosis, the suicidal erythrocyte death. Semin Cell Dev Biol 2015;39:35-42.

-9 Lang PA, Kaiser S, Myssina S, Wieder T, Lang F, Huber SM: Role of Ca2+-activated K+ channels in human erythrocyte apoptosis. Am J Physiol Cell Physiol 2003;285:C1553-C1560.

10 Abed M, Towhid ST, Mia S, Pakladok T, Alesutan I, Borst O, Gawaz M, Gulbins E, Lang F: Sphingomyelinaseinduced adhesion of eryptotic erythrocytes to endothelial cells. Am J Physiol Cell Physiol 2012;303:C991999.

11 Lau IP, Chen H, Wang J, Ong HC, Leung KC, Ho HP, Kong SK: In vitro effect of CTAB- and PEG-coated gold nanorods on the induction of eryptosis/erythroptosis in human erythrocytes. Nanotoxicology 2012;6:847856.

12 Maellaro E, Leoncini S, Moretti D, Del Bello B, Tanganelli I, De Felice C, Ciccoli L: Erythrocyte caspase-3 activation and oxidative imbalance in erythrocytes and in plasma of type 2 diabetic patients. Acta Diabetol 2013;50:489-495.

13 Bissinger R, Lang E, Ghashghaeinia M, Singh Y, Zelenak C, Fehrenbacher B, Honisch S, Chen H, Fakhri H, Umbach AT, Liu G, Rexhepaj R, Liu G, Schaller M, Mack AF, Lupescu A, Birnbaumer L, Lang F, Qadri SM: Blunted apoptosis of erythrocytes in mice deficient in the heterotrimeric G-protein subunit Galphai2. Sci Rep 2016;6:30925.

14 Lang E, Bissinger R, Fajol A, Salker MS, Singh Y, Zelenak C, Ghashghaeinia M, Gu S, Jilani K, Lupescu A, Reyskens KM, Ackermann TF, Foller M, Schleicher E, Sheffield WP, Arthur JS, Lang F, Qadri SM: Accelerated apoptotic death and in vivo turnover of erythrocytes in mice lacking functional mitogen- and stressactivated kinase MSK1/2. Sci Rep 2015;5:17316.

15 Bissinger R, Bouguerra G, Stockinger K, Abbes S, Lang F: Triggering of Suicidal Erythrocyte Death by Topotecan. Cell Physiol Biochem 2015;37:1607-1618.

16 Bouguerra G, Aljanadi O, Bissinger R, Abbes S, Lang F: Embelin-Induced Phosphatidylserine Translocation in the Erythrocyte Cell Membrane. Cell Physiol Biochem 2015;37:1629-1640.

17 Briglia M, Fazio A, Faggio C, Laufer S, Alzoubi K, Lang F: Triggering of Suicidal Erythrocyte Death by Ruxolitinib. Cell Physiol Biochem 2015;37:768-778.

18 Briglia M, Fazio A, Signoretto E, Faggio C, Lang F: Edelfosine Induced Suicidal Death of Human Erythrocytes. Cell Physiol Biochem 2015;37:2221-2230.

19 Calabro S, Alzoubi K, Faggio C, Laufer S, Lang F: Triggering of Suicidal Erythrocyte Death Following Boswellic Acid Exposure. Cell Physiol Biochem 2015;37:131-142. 


\section{Cellular Physiology Cell Physiol Biochem 2017;43:507-517 \begin{tabular}{l|l} 
and Biochemistry & DOI: 10.1159/000480477 2017 The Author(s). Published by S. Karger AG, Basel \\
www.karger.com/cpb
\end{tabular}

20 Egler J, Lang F: Licochalcone A Induced Suicidal Death of Human Erythrocytes. Cell Physiol Biochem 2015;37:2060-2070.

-21 Fazio A, Briglia M, Faggio C, Alzoubi K, Lang F: Stimulation of Suicidal Erythrocyte Death by Garcinol. Cell Physiol Biochem 2015;37:805-815.

$\checkmark 22$ Officioso A, Alzoubi K, Manna C, Lang F: Clofazimine Induced Suicidal Death of Human Erythrocytes. Cell Physiol Biochem 2015;37:331-341.

-23 Peter T, Bissinger R, Enkel S, Alzoubi K, Oswald G, Lang F: Programmed erythrocyte death following in vitro Treosulfan treatment. Cell Physiol Biochem 2015;35:1372-1380.

-24 Stockinger K, Bissinger R, Bouguerra G, Abbes S, Lang F: Enhanced Eryptosis Following Exposure to Carnosic Acid. Cell Physiol Biochem 2015;37:1779-1791.

25 Waibel S, Bissinger R, Bouguerra G, Abbes S, Lang F: Saquinavir Induced Suicidal Death of Human Erythrocytes. Cell Physiol Biochem 2015;37:1973-1982.

-26 Zierle J, Bissinger R, Egler J, Lang F: Lapatinib Induced Suicidal Death of Human Erythrocytes. Cell Physiol Biochem 2015;37:2275-2287.

27 Bissinger R, Waibel S, Bouguerra G, Al Mamun Bhuyan A, Abbes S, Lang F: Enhanced Eryptosis Following Exposure to Lopinavir. Cell Physiol Biochem 2015;37:2486-2495.

28 Briglia M, Fazio A, Faggio C, Lang F: Triggering of Suicidal Erythrocyte Death by Zosuquidar. Cell Physiol Biochem 2015;37:2355-2365.

29 Fazio A, Briglia M, Faggio C, Alzoubi K, Lang F: Oxaliplatin Induced Suicidal Death of Human Erythrocytes. Cell Physiol Biochem 2015;37:2393-2404.

30 Macczak A, Cyrkler M, Bukowska B, Michalowicz J: Eryptosis-inducing activity of bisphenol A and its analogs in human red blood cells (in vitro study). J Hazard Mater 2016;307:328-335.

31 Officioso A, Manna C, Alzoubi K, Lang F: Bromfenvinphos induced suicidal death of human erythrocytes. Pestic Biochem Physiol 2016;126:58-63.

32 Qadri SM, Donkor DA, Bhakta V, Eltringham-Smith LJ, Dwivedi DJ, Moore JC, Pepler L, Ivetic N, Nazi I, Fox-Robichaud AE, Liaw PC, Sheffield WP: Phosphatidylserine externalization and procoagulant activation of erythrocytes induced by Pseudomonas aeruginosa virulence factor pyocyanin. J Cell Mol Med 2016;10.1111/jcmm.12778

33 Zierle J, Bissinger R, Bouguerra G, Abbes S, Lang F: Triggering of Suicidal Erythrocyte Death by Regorafenib. Cell Physiol Biochem 2016;38:160-172.

34 Pagano M, Faggio C: The use of erythrocyte fragility to assess xenobiotic cytotoxicity. Cell Biochem Funct 2015;33:351-355.

35 Al Mamun Bhuyan A, Signoretto E, Bissinger R, Lang F: Enhanced Eryptosis Following Exposure to Dolutegravir. Cell Physiol Biochem 2016;39:639-650.

-36 Al Mamun Bhuyan A, Signoretto E, Lang F: Triggering of Suicidal Erythrocyte Death by Psammaplin A. Cell Physiol Biochem 2016;39:908-918.

-37 Mischitelli M, Jemaa M, Almasry M, Faggio C, Lang F: Stimulation of Suicidal Erythrocyte Death by Rottlerin. Cell Physiol Biochem 2016;40:558-566.

-38 Bissinger R, Bhuyan AA, Signoretto E, Lang F: Stimulating Effect of Elvitegravir on Suicidal Erythrocyte Death. Cell Physiol Biochem 2016;38:1111-1120.

39 Egler J, Zierle J, Lang F: Stimulating Effect of Manumycin A on Suicidal Erythrocyte Death. Cell Physiol Biochem 2016;38:1147-1156.

40 Mischitelli M, Jemaa M, Almasry M, Faggio C, Lang F: Stimulation of Erythrocyte Cell Membrane Scrambling by Quinine. Cell Physiol Biochem 2016;40:657-667.

41 Peter T, Bissinger R, Signoretto E, Mack AF, Lang F: Micafungin-Induced Suicidal Erythrocyte Death. Cell Physiol Biochem 2016;39:584-595.

42 Mischitelli M, Jemaa M, Almasry M, Faggio C, Lang F: Triggering of Suicidal Erythrocyte Death by Fascaplysin. Cell Physiol Biochem 2016;39:1638-1647.

43 Mischitelli M, Jemaa M, Almasry M, Faggio C, Lang F: Ca2+ Entry, Oxidative Stress, Ceramide and Suicidal Erythrocyte Death Following Diosgenin Treatment. Cell Physiol Biochem 2016;39:1626-1637.

44 Mischitelli M, Jemaa M, Almasry M, Faggio C, Lang F: Triggering of Erythrocyte Cell Membrane Scrambling by Emodin. Cell Physiol Biochem 2016;40:91-103.

45 Peter T, Bissinger R, Lang F: Stimulation of Eryptosis by Caspofungin. Cell Physiol Biochem 2016;39:939949. 


\section{Cellular Physiology Cell Physiol Biochem 2017;43:507-517 \begin{tabular}{ll|l} 
DOI: 10.1159/000480477 & $\begin{array}{l}\text { O 2017 The Author(s). Published by S. Karger AG, Basel } \\
\text { www.karger.com/cpb }\end{array}$
\end{tabular}}

Al Mamun Bhuyan et al.: ASP3026-Induced Eryptosis

46 Peter T, Bissinger R, Liu G, Lang F: Anidulafungin-Induced Suicidal Erythrocyte Death. Cell Physiol Biochem 2016;38:2272-2284.

47 Pretorius E, du Plooy JN, Bester J: A Comprehensive Review on Eryptosis. Cell Physiol Biochem 2016;39:1977-2000.

-48 Shan F, Yang R, Ji T, Jiao F: Vitamin C Inhibits Aggravated Eryptosis by Hydrogen Peroxide in Glucose-6Phosphated Dehydrogenase Deficiency. Cell Physiol Biochem 2016;39:1453-1462.

-49 Signoretto E, Honisch S, Briglia M, Faggio C, Castagna M, Lang F: Nocodazole Induced Suicidal Death of Human Erythrocytes. Cell Physiol Biochem 2016;38:379-392.

-50 Signoretto E, Laufer SA, Lang F: Stimulating Effect of Sclareol on Suicidal Death of Human Erythrocytes. Cell Physiol Biochem 2016;39:554-564.

-51 Signoretto E, Zierle J, Bissinger R, Castagna M, Bossi E, Lang F: Triggering of Suicidal Erythrocyte Death by Pazopanib. Cell Physiol Biochem 2016;38:926-938.

52 Wesseling MC, Wagner-Britz L, Huppert H, Hanf B, Hertz L, Nguyen DB, Bernhardt I: Phosphatidylserine Exposure in Human Red Blood Cells Depending on Cell Age. Cell Physiol Biochem 2016;38:1376-1390.

53 Zierle J, Bissinger R, Lang F: Inhibition by Teriflunomide of Erythrocyte Cell Membrane Scrambling Following Energy Depletion, Oxidative Stress and Ionomycin. Cell Physiol Biochem 2016;39:1877-1890.

54 Bissinger R, Modicano P, Alzoubi K, Honisch S, Faggio C, Abed M, Lang F: Effect of saponin on erythrocytes. Int J Hematol 2014;100:51-59.

55 Bissinger R, Modicano P, Frauenfeld L, Lang E, Jacobi J, Faggio C, Lang F: Estramustine-induced suicidal erythrocyte death. Cell Physiol Biochem 2013;32:1426-1436.

56 Lang E, Modicano P, Arnold M, Bissinger R, Faggio C, Abed M, Lang F: Effect of thioridazine on erythrocytes. Toxins (Basel) 2013;5:1918-1931.

-57 Al Mamun Bhuyan A, Bissinger R, Cao H, Lang F: Triggering of Suicidal Erythrocyte Death by bexaroten. Cell Physiol Biochem 2016;in press.:

58 Bissinger R, Barking S, Alzoubi K, Liu G, Liu G, Lang F: Stimulation of Suicidal Erythrocyte Death by the Antimalarial Drug Mefloquine. Cell Physiol Biochem 2015;36:1395-1405.

59 Bouguerra G, Bissinger R, Abbes S, Lang F: Stimulation of Eryptosis by Narasin. Cell Physiol Biochem 2015;37:1807-1816.

60 Signoretto E, Bissinger R, Castagna M, Lang F: Stimulation of Eryptosis by Combretastatin A4 Phosphate Disodium (CA4P). Cell Physiol Biochem 2016;38:969-981.

61 Signoretto E, Castagna M, Al Mamun Bhuyan A, Lang F: Stimulating Effect of Terfenadine on Erythrocyte Cell Membrane Scrambling. Cell Physiol Biochem 2016;38:1425-1434.

62 Signoretto E, Castagna M, Lang F: Stimulation of Eryptosis, the Suicidal Erythrocyte Death by Piceatannol. Cell Physiol Biochem 2016;38:2300-2310.

63 Al Mamun Bhuyan A, Bissinger R, Stockinger K, Lang F: Stimulation of Suicidal Erythrocyte Death by Tafenoquine. Cell Physiol Biochem 2016;39:2464-2476.

64 Alzoubi K, Egler J, Abed M, Lang F: Enhanced Eryptosis Following Auranofin Exposure. Cell Physiol Biochem 2015;37:1018-1028.

65 Almasry M, Jemaa M, Mischitelli M, Faggio C, Lang F: Stimulation of Suicidal Erythrocyte Death by Phosphatase Inhibitor Calyculin A. Cell Physiol Biochem 2016;40:163-171.

-66 Bissinger R, Bouguerra G, Al Mamun Bhuyan A, Waibel S, Abbes S, Lang F: Efavirenz Induced Suicidal Death of Human Erythrocytes. Cell Physiol Biochem 2015;37:2496-2507.

67 Faggio C, Alzoubi K, Calabro S, Lang F: Stimulation of suicidal erythrocyte death by PRIMA-1. Cell Physiol Biochem 2015;35:529-540.

68 Lang E, Pozdeev VI, Gatidis S, Qadri SM, Haussinger D, Kubitz R, Herebian D, Mayatepek E, Lang F, Lang KS, Lang PA: Bile Acid-Induced Suicidal Erythrocyte Death. Cell Physiol Biochem 2016;38:1500-1509.

69 Briglia M, Calabro S, Signoretto E, Alzoubi K, Laufer S, Faggio C, Lang F: Fucoxanthin Induced Suicidal Death of Human Erythrocytes. Cell Physiol Biochem 2015;37:2464-2475.

70 Jemaa M, Mischitelli M, Fezai M, Almasry M, Faggio C, Lang F: Stimulation of Suicidal Erythrocyte Death by the CDC25 Inhibitor NSC-95397. Cell Physiol Biochem 2016;40:597-607.

71 Abed M, Feger M, Alzoubi K, Pakladok T, Frauenfeld L, Geiger C, Towhid ST, Lang F: Sensitization of erythrocytes to suicidal erythrocyte death following water deprivation. Kidney Blood Press Res 2013;37:567-578. 


\section{Cellular Physiology Cell Physiol Biochem 2017;43:507-517 \begin{tabular}{c|c|c|c|} 
DOI: 10.1159/000480477 & O 2017 The Author(s). Published by S. Karger AG, Basel \\
www.karger.com/cpb
\end{tabular} \\ Al Mamun Bhuyan et al.: ASP3026-Induced Eryptosis}

72 Voelkl J, Alzoubi K, Mamar AK, Ahmed MS, Abed M, Lang F: Stimulation of suicidal erythrocyte death by increased extracellular phosphate concentrations. Kidney Blood Press Res 2013;38:42-51.

73 Lang E, Jilani K, Bissinger R, Rexhepaj R, Zelenak C, Lupescu A, Lang F, Qadri SM: Vitamin D-Rich Diet in Mice Modulates Erythrocyte Survival. Kidney Blood Press Res 2015;40:403-412.

74 Abed M, Artunc F, Alzoubi K, Honisch S, Baumann D, Foller M, Lang F: Suicidal erythrocyte death in endstage renal disease. J Mol Med (Berl) 2014;92:871-879.

-75 Ahmed MS, Langer H, Abed M, Voelkl J, Lang F: The uremic toxin acrolein promotes suicidal erythrocyte death. Kidney Blood Press Res 2013;37:158-167.

-76 Polak-Jonkisz D, Purzyc L: Ca(2+) influx versus efflux during eryptosis in uremic erythrocytes. Blood Purif 2012;34:209-210; author reply 210.

-77 Calderon-Salinas JV, Munoz-Reyes EG, Guerrero-Romero JF, Rodriguez-Moran M, Bracho-Riquelme RL, Carrera-Gracia MA, Quintanar-Escorza MA: Eryptosis and oxidative damage in type 2 diabetic mellitus patients with chronic kidney disease. Mol Cell Biochem 2011;357:171-179.

78 Bissinger R, Artunc F, Qadri SM, Lang F: Reduced Erythrocyte Survival in Uremic Patients Under Hemodialysis or Peritoneal Dialysis. Kidney Blood Press Res 2016;41:966-977.

79 Lang PA, Beringer O, Nicolay JP, Amon O, Kempe DS, Hermle T, Attanasio P, Akel A, Schafer R, Friedrich B, Risler T, Baur M, Olbricht CJ, Zimmerhackl LB, Zipfel PF, Wieder T, Lang F: Suicidal death of erythrocytes in recurrent hemolytic uremic syndrome. J Mol Med (Berl) 2006;84:378-388.

-80 Nicolay JP, Schneider J, Niemoeller OM, Artunc F, Portero-Otin M, Haik G, Jr., Thornalley PJ, Schleicher E, Wieder T, Lang F: Stimulation of suicidal erythrocyte death by methylglyoxal. Cell Physiol Biochem 2006;18:223-232.

81 Lang E, Gatidis S, Freise NF, Bock H, Kubitz R, Lauermann C, Orth HM, Klindt C, Schuier M, Keitel V, Reich M, Liu G, Schmidt S, Xu HC, Qadri SM, Herebian D, Pandyra AA, Mayatepek E, Gulbins E, Lang F, Haussinger D, Lang KS, Foller M, Lang PA: Conjugated bilirubin triggers anemia by inducing erythrocyte death. Hepatology 2015;61:275-284.

82 Qadri SM, Mahmud H, Lang E, Gu S, Bobbala D, Zelenak C, Jilani K, Siegfried A, Foller M, Lang F: Enhanced suicidal erythrocyte death in mice carrying a loss-of-function mutation of the adenomatous polyposis coli gene. J Cell Mol Med 2012;16:1085-1093.

83 Bissinger R, Kempe-Teufel DS, Honisch S, Qadri SM, Randrianarisoa E, Haring HU, Henes J, Lang F: Stimulated Suicidal Erythrocyte Death in Arteritis. Cell Physiol Biochem 2016;39:1068-1077.

84 Kempe DS, Akel A, Lang PA, Hermle T, Biswas R, Muresanu J, Friedrich B, Dreischer P, Wolz C, Schumacher U, Peschel A, Gotz F, Doring G, Wieder T, Gulbins E, Lang F: Suicidal erythrocyte death in sepsis. J Mol Med (Berl) 2007;85:273-281.

85 Bissinger R, Schumacher C, Qadri SM, Honisch S, Malik A, Gotz F, Kopp HG, Lang F: Enhanced eryptosis contributes to anemia in lung cancer patients. Oncotarget 2016;7:14002-14014.

-86 Lang PA, Schenck M, Nicolay JP, Becker JU, Kempe DS, Lupescu A, Koka S, Eisele K, Klarl BA, Rubben H, Schmid KW, Mann K, Hildenbrand S, Hefter H, Huber SM, Wieder T, Erhardt A, Haussinger D, Gulbins E, Lang F: Liver cell death and anemia in Wilson disease involve acid sphingomyelinase and ceramide. Nat Med 2007;13:164-170.

87 Lupescu A, Bissinger R, Goebel T, Salker MS, Alzoubi K, Liu G, Chirigiu L, Mack AF, Qadri SM, Lang F: Enhanced suicidal erythrocyte death contributing to anemia in the elderly. Cell Physiol Biochem 2015;36:773-783.

88 Lang E, Pozdeev VI, Xu HC, Shinde PV, Behnke K, Hamdam JM, Lehnert E, Scharf RE, Lang F, Haussinger D, Lang KS, Lang PA: Storage of Erythrocytes Induces Suicidal Erythrocyte Death. Cell Physiol Biochem 2016;39:668-676.

89 Li T, LoRusso P, Maitland ML, Ou SH, Bahceci E, Ball HA, Park JW, Yuen G, Tolcher A: First-in-human, openlabel dose-escalation and dose-expansion study of the safety, pharmacokinetics, and antitumor effects of an oral ALK inhibitor ASP3026 in patients with advanced solid tumors. J Hematol Oncol 2016;9:23.

90 Ibrahim UA, Yusuf AA, Ahmed SG: The Pathophysiologic Basis of Anaemia in Patients with Malignant Diseases. Gulf J Oncolog 2016;1:80-89.

91 Mhaskar R, Wao H, Miladinovic B, Kumar A, Djulbegovic B: The role of iron in the management of chemotherapy-induced anemia in cancer patients receiving erythropoiesis-stimulating agents. Cochrane Database Syst Rev 2016;2:Cd009624. 


\section{Cellular Physiology Cell Physiol Biochem 2017;43:507-517 \begin{tabular}{ll|l|l} 
DOI: 10.1159/000480477 & $\begin{array}{l}\text { O 2017 The Author(s). Published by S. Karger AG, Basel } \\
\text { www.karger.com/cpb }\end{array}$ \\
\hline and Biochemistry & Published online: September 20, 2017
\end{tabular}}

Al Mamun Bhuyan et al.: ASP3026-Induced Eryptosis

92 Testa U, Castelli G, Elvira P: Experimental and investigational therapies for chemotherapy-induced anemia. Expert Opin Investig Drugs 2015;24:1433-1445.

$\$ 93$ Shah N, Andrews J, Goodnough LT: Transfusions for anemia in adult and pediatric patients with malignancies. Blood Rev 2015;29:291-299.

-94 Lamy PJ, Durigova A, Jacot W: Iron homeostasis and anemia markers in early breast cancer. Clin Chim Acta 2014;434:34-40.

95 Gaspar BL, Sharma P, Das R: Anemia in malignancies: pathogenetic and diagnostic considerations. Hematology 2015;20:18-25.

-96 Gilreath JA, Stenehjem DD, Rodgers GM: Diagnosis and treatment of cancer-related anemia. Am J Hematol 2014;89:203-212.

97 Gao S, Ma JJ, Lu C: Venous thromboembolism risk and erythropoiesis-stimulating agents for the treatment of cancer-associated anemia: a meta-analysis. Tumour Biol 2014;35:603-613.

-98 Adamson JW: Iron, erythropoietic stimulating agents, and anemia in cancer. Crit Rev Oncog 2013;18:471483.

$\$ 99$ Harrison HE, Bunting H, Ordway NK, Albrink WS: The Pathogenesis of the Renal Injury Produced in the Dog by Hemoglobin or Methemoglobin. J Exp Med 1947;86:339-356.

100 Borst O, Abed M, Alesutan I, Towhid ST, Qadri SM, Foller M, Gawaz M, Lang F: Dynamic adhesion of eryptotic erythrocytes to endothelial cells via CXCL16/SR-PSOX. Am J Physiol Cell Physiol 2012;302:C644-C651.

101 Andrews DA, Low PS: Role of red blood cells in thrombosis. Curr Opin Hematol 1999;6:76-82.

102 Chung SM, Bae ON, Lim KM, Noh JY, Lee MY, Jung YS, Chung JH: Lysophosphatidic acid induces thrombogenic activity through phosphatidylserine exposure and procoagulant microvesicle generation in human erythrocytes. Arterioscler Thromb Vasc Biol 2007;27:414-421.

103 Zwaal RF, Comfurius P, Bevers EM: Surface exposure of phosphatidylserine in pathological cells. Cell Mol Life Sci 2005;62:971-988.

104 Closse C, Dachary-Prigent J, Boisseau MR: Phosphatidylserine-related adhesion of human erythrocytes to vascular endothelium. Br J Haematol 1999;107:300-302.

105 Gallagher PG, Chang SH, Rettig MP, Neely JE, Hillery CA, Smith BD, Low PS: Altered erythrocyte endothelial adherence and membrane phospholipid asymmetry in hereditary hydrocytosis. Blood 2003;101:46254627.

106 Pandolfi A, Di Pietro N, Sirolli V, Giardinelli A, Di Silvestre S, Amoroso L, Di Tomo P, Capani F, Consoli A, Bonomini M: Mechanisms of uremic erythrocyte-induced adhesion of human monocytes to cultured endothelial cells. J Cell Physiol 2007;213:699-709.

107 Wood BL, Gibson DF, Tait JF: Increased erythrocyte phosphatidylserine exposure in sickle cell disease: flowcytometric measurement and clinical associations. Blood 1996;88:1873-1880. 